This is the accepted version of the article Pedagogical challenges involving race, gender and the unwritten rules in settings of higher education

\author{
Authors: Gillian U. Bayne and Eduardo Dopico
}

This paper was published in Cultural Studies of Science Education, 15. 623-637

Doi: https://doi.org/10.1007/s11422-020-09972-w

\title{
Pedagogical challenges involving race, gender and the unwritten rules in settings of higher education
}

\author{
Gillian U. Bayne ${ }^{1} \cdot$ Eduardo Dopico $^{2}$ \\ 1 Department of Middle and High School Education, Lehman College, City University of \\ New York, \\ New York, USA \\ 2 Department of Education Sciences, University of Oviedo, Oviedo, Asturias, Spain \\ Cultural Studies of Science Education. https://doi.org/10.1007/s11422-020-09972-w
}

\begin{abstract}
In this discussion paper, we highlight a few interesting and important concerns that have been identified in a diverse number of scholars' work. The successive upsurges of racism and sexism in our spaces of coexistence require us to reflect and confront pedagogical challenges, which remain deadlocked in the field of science education. We explore instances of how racism and sexism infiltrate spaces in higher education, specifically science education, and how race consciousness and consciousness of sexism can positively influence hierarchical systems and popular mindsets that exist in academia. The roles that "colorblindness" play as a so-called reality in academia are interrogated, as are the unwritten rules of teaching, learning, collaborating, researching, writing and serving one's community. Pedagogical challenges posed to Black science education faculty which encompass characteristics and practices that oftentimes include, for example, experiencing a lack of respect, devaluation, the questioning of scholarly credibility and professional credentials and the authenticity of one's work are examined critically. Finally, we juxtapose the aforementioned experiences, with examples of possibilities that can exist when future and forward thinking about race, racism and sexism takes place in science and science education.
\end{abstract}

Keywords Race - Gender - Critical consciousness - Unwritten rules · Science education · Pedagogical challenges

\section{Resumen}

En este artículo de discusión, intentamos destacar algunas inquietudes interesantes e importantes que se han ido identificando en diversos trabajos académicos. El progresivo aumento del racismo y el sexismo en nuestros cespacios de convivencia requieren que reflexionemos y confrontemos sobre los desafíos pedagógicos que siguen estancados en el campo de la educación científica. Aquí, exploramos algunos ejemplos de cómo el racismo y el sexism se infiltran en los espacios de la educación superior, específicamente en la educación científica, y cómo la conciencia racial y la conciencia del sexismo pueden influir positivamente en los sistemas jerárquicos y las 
mentalidades populares que existen en la Educación Superior. También es cuestionado el rol que la negación interesada del color de piel "colorblindness" juega en la cotidianeidad de los espacios universitarios, al igual que las reglas no escritas de enseñanza, aprendizaje, colaboración, investigación, publicación científica y servicio a la

comunidad. Los desafíos pedagógicos planteados a los profesores negros en las facultades de educación científica, que abarcan características y prácticas que a menudo incluyen, por ejemplo, experimentar una falta de respeto, devaluación, el cuestionamiento de la propia credibilidad académica, las credenciales profesionales o la autenticidad del trabajo de uno, se examinan críticamente. Finalmente, yuxtaponemos las experiencias antes mencionadas, con ejemplos de posibilidades que pueden existir cuando un pensamiento futuro y más avanzado sobre la raza, el racismo y el sexismo ocupe su lugar en la ciencia y la educación científica.

Scholarly work within the domain of cultural studies helps us to dissect some of the tensions that are inherent in the culture of pedagogical practices (Kirylo 2013). Eileen Carlton Parsons, Domonique L. Bulls, Tonjua B. Freeman, Malcom B. Butler and Mary M. Atwater (2018) detail the experiences and perceptions of Black science education faculty members who teach, research and engage in a variety of activities, both in the academic community and the community at large. This important work functions as a springboard for us to discuss some of the undesirable and anti-pedagogical elements that seriously impact science education-most specifically, those that relate to racism and sexism.

Racism, as Michael Dyson, a Black professor of sociology, has stated, "presupposes the ability to control a significant segment of the population-economically, politically and socially - by imposing law, covenant and restriction on their lives" (BETNetwork 2012, 1:49). It is a relatively new term (its first definition in the Larousse dictionary is from 1932) and describes the action of overvaluing the characteristics of a culture that we compare with another, while underestimating the latter (Arnáiz Sánchez and Escarbajal Frutos 2012). Sexism, discrimination based on a person's sex or gender, is commonly linked to stereotypes and gender roles that can include beliefs held that presupposes one gender or sex being inherently superior to another. To be in the world as a person who critically experiences life, and the need to become more fully aware of its unfolding, one must be dedicated to questioning, reflecting and taking action that is thoughtful, timely and appropriate for the given situation. These factors are all fundamental to becoming more conscious-more present in life, while becoming more aware of matters that are tough topics to discuss and matters that address aspects of the world that are steeped in the destructive cycles of racism, sexism, deficit thinking, talk and action. These cycles are experienced as hard to discuss for many reasons, including the generation of uncomfortable feelings, and contentious discussions that can result in damaged professional relationships and careers. Additionally, the hard-held notion by many in the field is science and science education that are objective, without considering the nature by which historiography influences both is problematic. Issues including racism, sexism and deficit views of others are rendered irrelevant, therefore, because of such fixed mindsets. Ingrained within these dangerous cycles are issues involving power, justice and democracy that mandate ethical decency-in both beliefs and practices. Bold and forthright strategies, including strong political will, a large amount of financial investment, the breaking of deeply rooted stereotypes and changing institutionally honored mindsets that have done more harm than good, are needed to address these very difficult challenges in order to effect change (Valencia 2010). But most importantly perhaps, it is the need to acknowledge that the problem exists, and that we need scholars in the social sciences, Africana studies, cultural ethnic and gender studies and a variety of other scholarly and practitioner-based domains to contribute widely to addressing racism and sexism that are specifically embedded within science education. Through shared information and collaborative scholarly work, an exploration into how to specifically address difficult issues through the applications of professional and pedagogical practices that are aligned to critical race theory, culturally aligned 
education, intersectionality, and more, into professional and pedagogical practices can occur. Encouraging participation in reflective practices that are grounded in critical analyses and in understanding the negative effects of reprehensible and destructive social norms (Goncalo, Katz and Ellis 2018), along with the triggering of significant periodic events in moments of great discrimination (Law and Legewie 2018), can be useful. Engaging in positive practices that afford change is important, as these highly difficult and emotional events almost always determine how social life is shaped and how it develops and unfolds in academia (e.g., Rodgers 2002; Loughran 2002).

\section{Toward humane beliefs and practices}

Through studying and adopting practices that have been successful in thinking about and affecting change in other disciplines as it relates to race and gender, science and science education will move productively toward being positively transformed. For example, R. G. Bagnall (1999) encourages us to not only become increasingly cognizant of individuals' social roles and personal beliefs, but to also become more humane in the profession and practice of [science] education. Bagnall posits that through the development of six closely connected and often interwoven qualities, namely (a) reflexive awareness; (b) individual and organizational responsibility; (c) tolerance of and respect for difference; (d) sympathetic understanding of, and responsiveness to, lived events; (e) respect for persons and their realities; (f) the negotiation of discriminative realities; and $(\mathrm{g})$ the alleviation of discriminative injustice, we can endeavor to continue to develop into individuals who are more aware, sympathetic and tolerant of others.

\section{The critical domain affecting change}

On this reconstruction of individual and social consciousness, the critical domain calls for examining the impacts that power, money, religion, race, gender and culture have on how society, history and education mediate lived experiences. Joe Kincheloe identifies the critical domain's importance (1997), in that it is used to examine the impacts by: (a) rejecting positivistic notions of rationality, truth and objectivity; (b) having awareness of the relationship between personal values and their practices; (c) becoming cognizant of the social and political construction of professional consciousness; and (d) uncovering aspects of the dominant social order that undermines democratic goals (1999). Engaging in the critical domain, specifically in science education, helps to create an understanding of how these elements - power, money, religion, race, gender and culture-historically and in contemporary times have been used to both facilitate and impede experiences in the academy. By understanding history, possibilities and actualities of change needed to move toward more just and equitable experiences can be had. Hence, what we propose is a positive fundamental change in the academic traditions, which oftentimes keep Black science education faculty at the margins of the profession. The critical domain calls for an examination of how the academic tradition of teaching and learning science will change when implications related to race and gender are made evident. There must not be reprimands, penalizations or engagement in even worse activities when confronting racism's and sexism's ugliness and hurtfulness. The need to work toward increasing mutual respect and understanding by respecting our differences and finding strength and power in them is in order. Kincheloe posits that "the inequalities of contemporary society need to be addressed, and that the world [of science education] would be a better place if such unjust realities could be changed" (2008, p. 1191).

\section{Developing awareness}

Sylvia Wynter (1987) identifies the race aspect of the critical domain by asking the question, what does it mean to be human? Wynter sheds light onto the importance of developing the awareness of our "ideological hegemonies - race principal among them"-(McKittrick 2015) in order to become more conscious of how our schema and practices impact the ways that life unfolds. She argues for the need to reconstruct an understanding of the foundation of human 
being - the phenomenology of what it means to be human in the world - "a reconstruction that entails a deeper grasp of the dimensions of human cognition and human action" (Scott 2000, p. 121). This movement toward reconstructing understanding to enable change, whether catalyzed by racial and/or gender tensions which have been forced upon individuals externally, or driven from an internal shift, is necessary in order to uncover and confront aspects of dominant social orders that undermine just goals. Within conscious science and science education pedagogical practices, this process of change needs to be included in the curriculum because it affects not only educational professionals, but also students who must share their personal lived experiences, both inside and out of classroom situations, as these locations are where many of the social injustices that wreak havoc on communities are rooted (Madden, Wong, Vera Cruz, Olle and Barnett 2017). The process of change might include, for example, introducing a critical perspective of the social hierarchical organization of educational systems, and the nature of egalitarian human relations within various science content and education programs in higher education. Discussions and mutual agreements can bring about the potential to strengthen soft skills (interpersonal, social and professional competences) - skills that can be learned, utilized and modeled after so that not only educators and administrators can benefit from their practices, but also these individuals can also be encouraged to think more critically and enact improved changes that will enable students to learn from the modeled behaviors.

\section{Race, gender and consciousness}

In these times of increasing authoritarianism around the world (Grioux 2017; Peters 2018), we are reminded of the deep-rooted nature of complexities of identities and culture in race and gender consciousness. Recognition of these complexities underscores the need to identify, understand, reflect upon and take action toward preventing and eradicating the enormous amount of harm that racist and sexist mindsets and actions bring about, for people of color and women in science and science education. By not acting justly in personal spaces, in education and in every aspect of the makings and workings of society along racial and gender lines, cryptic positivistic mindsets are fortified.

\section{The culture of racism}

While scientists (Haney Lopez 2000; Zack 2018) concur that the notion of race is a social construct, belief systems exist that espouse race as being nonexistent, unimportant or even something that is not really experienced and therefore without relevance historically in the twenty-first century. Culture has been described as the dynamic interaction between beliefs and practices (Sewell 1999). Thus, it can be argued that racism has characteristics of a culture and exists for many reasons, including gains that can be had educationally, professionally and institutionally. Oppressive thinking and practices inherent to racism get enacted simultaneously, whether at a subliminal or conscious level (Capper 2015). They are key factors in the system that can define people in all aspects of life, as racist thoughts and actions assume control over education, health care, income and politics. Racial microaggressions have been defined as "brief and commonplace daily verbal, behavioral and environmental indignities, whether intentional or unintentional, that communicate hostile, derogatory, or negative racial slights and insults to the target person or group" (Sue et al. 2007, p. 273). Microaggressions that are common can include, for example, assigning negative stereotypes, directing inquiring and insulting glances, articulating unwarranted opinions about others, treating someone unfairly and differently from others and making rude comments. The problem with microaggressions is that they are practiced systematically and intentionality, and most of the time they are not perceived by those doing them as being hurtful and/or harmful. In this way, it is difficult to raise awareness about them and act against them.

Consider the following scenario: Two Black science education faculty members (John

Brown and Helen Smalls, both pseudonyms, male and female, respectively) who work in the 
same department are invited to meet with a White male science faculty member, Robert Hall (pseudonym), to share ideas about a potential collaboration. While both John and Helen were invited and only one of them was actually needed to be in attendance, the science education colleagues decided that John would attend the meeting and Helen would attend the next one. Upon his arrival, Robert greeted John and asked him facetiously, "Where's your girlfriend?" John laughed it off and said that Helen would attend the next meeting. Despite the fact in this scenario that all three faculty members were tenured and had been teaching at the same university for some time, Robert did not ask John, "Where's your colleague?" or "Where's Helen?" or "Where's Dr. Smalls?" John giggled when he told Helen how Robert had asked about her and followed the retelling of the experience by laughing, while asking, "Can you believe that?" Replying seriously, Helen said to John, "Firstly, it was completely inappropriate for Robert to ask for me in the manner that he did. I am not your girlfriend but I am legitimately your colleague. And, secondly, I find that your retelling of the story in the manner that you did, giggling and thinking that it was funny, is a second insult, especially given the hurdles that we have both encountered in the academy." In this scenario, it can be argued that Helen had been a victim of sexist and professional microaggressions - by both Robert and John. Robert's microaggression involved his referral to Helen as John's girlfriend. This microaggression could also fall under one that is racial-of both John and Helen-depending on what was going on in Robert's mind as he said what he said. John's fault rested in laughing and making light of the encounter.

John's microaggression toward Helen was likely not only of a sexist nature, but one of a professional one as well. As depicted here, the culture of microaggressions is a by-product of the culture of racism (Christian 2017). Commonly, this culture is grounded not only in racism (Lawrence 2018), but in sexism as well (McMahon and Kahn 2018).

"Race" has its roots in pseudoscience, and racism has had a long history within many of the sciences as we know of them today. Stephen J. Gould, noted paleontologist, evolutionary biologist and historian of science, provides ample evidence, in The Mismeasure of Man (1981), and debunks hard-held deficit pseudoscientific views related to race, including phenology, the bell curve, eugenics and more. Black people have been victims of racism widely, as evidenced by the injustices executed in, for example, a vast array of medical experiments (Washington 2008), the Tuskegee experiments (CDC, https ://www.cdc.gov/

tuske gee/timel ine.htm), in gynecological practices (Cooper-Owens 2017), radiation trials (Smith 2018), and through the use of Henrietta Lacks's (HeLa) cells-cells, "used to help develop our most important vaccines and cancer medications, in vitro fertilization, gene mapping, cloning" (Skloot 2013). These are but a few of the enormous injustices hurled upon Black people and so beg the questions that one of our students asked, "In 2019, why aren't Black scholars respected after the science of inferiority was debunked? Why aren't you [as Black science educators] respected? If science positivistically regarded race as a social construction, why aren't all scientists [and science educators] 'created equal'? Why don't you get the respect that you deserve?" We believe that a large part of the issues related to race is grounded in fear-perhaps fear of racists losing the benefits and rewards experienced because of being in positions of control, power, privilege and entitlement; fear of being outsmarted, overpowered or of themselves being the victims of oppression - the same oppression which they used to oppress others. Surely, there are a myriad of fears, and the fears are strong enough to continue and even deepen racist ways of being. Sadly, the embodiment of these fears hurts everyone.

\section{Urban scientist or whore?}

Consider, for example, the widely noted 2013 case of Dr. Danielle N. Lee. Dr. Lee is a Black female scientist who at that time had written regularly in blogs at Scientific American's Web site. In the magazine's Urban Ecology blog, Dr. Lee had been invited to write on many issues, including those that involve urban ecology, evolutionary biology and diversity in the sciences. Dr. Lee was invited to contribute to Biology Online, another science Web site. When she posed the 
question of how much she would be compensated fo her contribution to Biology Online, an editor only identified as "Ofek" responded to her question by saying quite matter-of-factly that there would be none. "Thank you very much for your reply," Dr. Lee wrote back, "but I will have to decline your offer. Have a great day." The editor's response was: "Because we don't pay for blog entries? Are you an urban scientist or an urban whore?" (Curry 2013). In her scholarly work, Sister Citizen: Shame, Stereotypes and Black Women in America, Melissa Harris Perry (2011) delves deeply into the historically rooted negative stereotypes of Black American women, as is evidenced today by Dr. Lee's experience. There is clearly a normalized prevalence of racist, classist and sexist sentiments in today's society. Instances of racism, classism and sexism and the solidified culture of disrespect have no place in the field of science, science education and in society at large. Yet, they exist, in Dr. Lee's case and in too many more cases-all in plain view. The disheartening and disconcerting part of it all is that all science educators are involved in the teaching and learning of science, how to be involved in science, and serve as role models for many in the sciences and elsewhere. Yet, Black scientists and science educators continue to be stereotyped negatively and cast as unequal. Kimberlé Crenshaw, a noted Black female leading scholar of critical race theory, and a civil rights advocate, who specializes in issues involving gender and race, is known for her important work on intersectionality (1989). Crenshaw's intersectionality work is focused on how systems of oppression factor into the social identities of people of color. She explains that intersectionality is used as a lens through which one can see where power is situated, where it collides and where it intersects and interlocks (1989). This lens sheds light on the ways that forms of racism, sexism and classism merge, overlap and intersect in the lived experiences of marginalized people. When considering the editor's response to Dr. Lee's question about being compensated for her contribution to Biology Online, one interpretation could be that he is equating "urban" to being Black, and because of her Black race and her gender, Dr. Lee is therefore relegated to a "whore" status. bell hooks (1981), Black feminist and social activist, has emphasized that in order to have the ongoing practices of domination, sexism and discrimination, it is crucial to be silent. Dr. Lee clearly was not. Through her response to Biology Online, she delivered a thoughtful, tactful and appropriate fine example of what it takes to expose, confront and oppose sexism, racism and classism in the moment, as the interaction itself unfolded. She said that the name-calling that was thrust upon her was dismissive and that the ideas of being paid in exposure, instead of US currency, was not right. In a blog, and in her own words, Lee (2013) effectively addressed the insult:

_ It wasn't just that he called me a whore - he juxtaposed it against my professional being: Are you urban scientist or an urban whore? Completely dismissing me as a scientist, a science communicator (whom he sought for my particular expertise), and someone who could offer something meaningful to his brand. What? Now, I'm so immoral and wrong to inquire about compensation? Plus, it was obvious to me that I was supposed to be honored by the request.

_ After all, Dr. Important Person does it for free so what's my problem? ...Folks have reasons - finances, time, energy, aligned missions, whatever - for doing or not doing things. Seriously, all anger aside...this rationalization of working for free and you'll get exposure is wrong-headed. This is work. I am a professional. Professionals get paid. End of story. Even if I decide to do it pro bono (because I support your mission or I know you, whatevs) - it is still worth something. I'm simply choosing to waive that fee. (para. 4)

\section{A refusal to see}

Just as racism exists for many purposes, so too does the notion of colorblindness (Mekawi, Bresin and Hunter 2017) - that strange tendency to refuse to acknowledge its existence or acknowledge 
that race is a factor in interactions. However, colorblindness is used as a pattern of behavior to negate the occurrence of racism (Plaut, Thomas, Hurd and Romano 2018) and serves as a privilege for those in authority to ignore the cultural and societal impacts of racial differences. "Colorblindness" also becomes a very convenient crutch that readily gets accessed and appropriated, especially within the arena of the teaching, learning and researching of science and science education (Dixson and Rousseau Anderson 2018). It is during these activities when the necessity to engage in critical consciousness occurs, so that when someone, for example, in the academe or in a science classroom says "I don't see color" or "Race doesn't matter in science or science education," we must interrogate the deliverer of those statements. Is the deliverer really saying, "I don't see you" or "Your experience as a Black faculty member doesn't matter" (despite the fact that you are the only person of color in our science education department, and despite the fact that science and science-related fields are dominated by white men)?

\section{Conscientização}

Paulo Freire, known for his important work on conscientizacão, or critical consciousness, has emphasized the importance of working toward and achieving in-depth understandings of the world and its contradictions, especially as they relate to social, economic and political issues. The foundations of enacting critical consciousness (Freire 1972) are experienced when taking action against oppressive forces, like those that occur with the dismissal of race as an important factor in many aspects of how social life develops. Educators have the opportunity to demand a change in the culture of science education as a means to fight ignorance through knowledge. When oppressive forces are recognized and reflected upon, what needs to follow is the taking of action toward understanding the enormity of the consequences that can and do occur by not acting justly in personal experiences, in education and in every aspect of the makings and workings of society as they relate, for example, specifically to race (Godfrey and Wolf 2016). This requires strong advances toward an inclusive policy so that change can and does occur. Adhering to an educational policy that generates positive outcomes will have an effect on how individuals interact with each other, which will have ripple effects and will be instrumental in changing the culture of the academy to one that becomes increasingly inclusive of people along the lines of gender and race.

\section{Unwritten rules and privilege}

From a phenomenological framework, we approach our daily lives as integrated in a sociocultural reality where intersubjective symbolic relations originate (Dreher 2003). It is in this relational reality that we can discover limited areas of meaning, unwritten rules that regulate assumed meanings, and those that are reproduced through life experiences, and are concretized in the spaces within which they occur (Berger, Luckmann and Zifonun 1991). Research conducted by Parsons, Bulls, Freeman, Butler and Atwater (2018) provides insights into the life stories (Gulbrium and Holstein 2002) of Black female and male professor participants who work within the culture of corporate organizations (Barnes and Smith 2013), and from the perspective of racialized and gender laden climates on campuses of higher education (Ward and Zarate 2015), where labor practices and the valid personal experience of educators and students are juxtaposed (Leath and Chavous 2017). The research evidenced that Black faculty are constantly forced to navigate challenges involving diversity. Race and gender are central in the description of these experiences, but so too is the set of unwritten rules that influence organizational procedures and affect the work environment (Virtanen and Elovainio 2018).

In education, curricular contents that are implicitly transmitted, without previously being critically reflected upon, are often referred to as the hidden curriculum (Alsubaie 2015). This hidden curriculum also activates learning and beliefs that are not included in official schools documents (McCaughey and Cermele 2017). That is, on one hand there exists formal curriculum, where teaching and learning are explained in detail. On the other hand is the hidden curriculum, 
which is developed in everyday practices through the interactional exchanges between educational agents. Black faculty participants experience the same hidden curriculum, where the gap, especially as it relates to women, is clearly reflected between reality and expectations (Wright, Maylor and Watson 2018). These Black faculty have voiced that they feel restrained, are bogged down in administrative responsibilities, are generally misunderstood by their majority students and have suffered grave repercussions for trying to give students the tools and a better understanding of how (well) they need to be prepared to teach and work with an increasingly diverse student population (Stronge 2018).

\section{Teaching, research, administrative tasks and the community}

Usually, an education professional in higher education is focused on the following categories: teaching, engaging in scholarly work and research, cooperating with and enacting administrative tasks and being active in one's educational community and the community at large. College professors can experience these required tasks as being clear, or not so clear (Ellis and Hogard 2018). In one way or another, the practice resulting from the perception of professional practice can affect an entire program, department, school and college. In an ideal working climate, faculty collaborate so that these tasks get enacted with the greatest possible diligence, care and quality, while taking into account the overall educational and research objectives of the institution. In this way, university professors, while designing the most up-to-date and motivating class materials, strives toward translating these efforts effectively into the classroom. They are involved in ongoing research, of which they intend to publish and in most instances promptly. Administrative tasks that allow them to be current with structural and functional rules and regulations necessary for academic competence, tutorials with students and research team meetings, for example, are also practices that are necessary to undertake in order to be in compliance with college, local and national requirements. The overarching focus is placed upon striving to achieve the best teaching ratings, among other things. Although it remains debatable whether or not student evaluations might measure teaching effectiveness (Braga, Paccagnella and Pellizzari 2014; Uttl, White and Gonzalez 2017), they tend to weigh heavily not just on Black professors (Croom 2017) but on women professors as well (Mitchell and Martin 2018).

Teaching is important, and continuing professional development in pedagogical training (Linnemanstons and Jordan 2017) allows professors to improve their teaching competences, as dictated by university frameworks. Research is extremely important as well, and professors need to publish papers in high-impact journals to disseminate their research (Decker and Odom 2018). The known narrative is that by engaging in these practices, a professor's likelihood of promotion or employment stabilization and the funding of research and research teams are said to be very possible. Adding on to these "requirements," professors, like other professionals, find themselves involved in a multitude of bureaucratic tasks. Being an active member of the academy is certainly not a simple job, but a "true" professor is committed to it, assumes the responsibility that is associated with it and is able to that an academic's salary is hardly commensurate with the amount of work required to do one's job well. Despite this reality, professors press on working hard to produce highquality outcomes efficiently and effectively. In spite of experiencing the profession as most times being quite rewarding, the academic working environment may not be ideal. Behind that public mask, we can sense that there is a pedagogical juxtaposition between the hidden curriculum and all kinds of unwritten rules that surround the workplace, as they are embedded in the organizational structures and in the decision-making processes. The reality is that gradually, while trying to engage in the work responsibly, one discovers some of what has been hidden (Imrie, Cox and Miller 2014). Tensions that are generated by the contradictions from one's expectations, the institution's expectations and the need to balance work and family are generally very difficult to manage. When unwritten rules are added to these tensions, attending to a faculty member's work becomes even harder. We face experiences that make teaching and its 
related tasks much more difficult. These hidden rules deepen racial and gender biases on campuses (Mazer 2018) and can oftentimes block promotion in scientific and educational leadership (Knobloch-Westerwick, Glynn and Huge 2013). Additionally, such practices create indelible marks of racism and sexism within university spaces. The effects of surviving in such challenging, emotionally, physically and psychologically draining environments manifest in a variety of forms and create unnecessary job dissatisfaction that eventually can lead to a burnedout professional. All of these factors create undesirable outcomes and prevent the most meaningful, equitable circumstances for the best experiences to take place.

\section{Pedagogical challenges and privilege}

Racism is unacceptable and should not be tolerated in any social space, especially in the seat of knowledge - in our coveted academic environments. But racism neither originates in school, nor does it originate "on the street." Social contexts are omnipresent, and all are important in the socialization of individuals. Vygotsky (1986, revised edition) posits that sociocultural learning occurs within all types of environments.

\section{Racism: a culture}

Culture is grounded in the attitudes, values, beliefs and knowledge that a society shares (Matusov and Marjanovic-Shane 2017). Culture helps to define how a community organizes and classifies reality. It is built around the notion that the members of that society accept their culture as their truth and, therefore, tend not to question it. This idea can lead to the consideration that culture is an unscientific element. As such, it is the culture in which we live that produces and reproduces racism. The capability and power to transform it, therefore, is in all environments and within all contexts. It is the people themselves who will need to work hard at changing it. As Parsons, Bulls, Freeman, Butler and Atwater (2018) state, racism exists with or without people's conscious awareness of race, and so it is: being aware or not being aware of this reality does not eliminate reality. Only enforced policy, our free will and the humanization of every man woman and child, irrespective of race or ethnicity, will lead us toward addressing such a dangerous, debilitating problem. Science questions reality and does not simply accept the "truth" as being something not to be questioned. As such, many consider there to only be certainties based on physical, tangible evidence. With this scientific reasoning, we can affirm that racism and racist behavior are cultural values based on ignorance. Popper (1945) said that true ignorance is not the absence of knowledge, but the refusal to acquire it. Racism is built on values based on evil, as Arendt would say (2004). Since culture can be viewed or experienced as a dialectical relationship of schema and practices, a system of symbols and meanings (Sewell 1999), a critical analysis of the culture of the academy is in order. It behooves the academy, to analyze its structure and how its structure affords, and some would argue, mandates a culture of both sexism and racism. Within this analysis, it is essential to operationalize specific enactable and mandatable measures toward dismantling those structures within which racism exists, and continues to be both rooted and supported.

\section{Invisibility}

Peggy McIntosh, feminist and antiracist scholar, is widely known for her writings on white and male privilege. In her work, White Privilege: Unpacking the Invisible Knapsack (1998), she details many of the privileges that she had taken for granted because of her race that people of color do not readily have. She writes, "I realized I had been taught about racism as something that puts others at a disadvantage, but had been taught not to see one of its corollary aspects, white privilege, which puts me at an advantage." Upon critical reflection of her own privilege, McIntosh shares, for example, some of her own: (a) being able to "speak in public to a powerful male group without putting my race on trial,"; (b) "do[ing] well in a challenging situation without being called a credit to my race,"; (c) "going home from most meetings of organizations I belong 
to feeling somewhat tied in, rather than isolated, out-of-place, outnumbered, unheard, held at a distance, or feared"; and (d) "tak[ing] a job with an affirmative action employer without having co-workers on the job suspect that I got it because of race." (McIntosh 1998).

It is quite easy to suggest that in order to understand what the trials and tribulations that Black science education faculty face, one must put oneself in the shoes of the other. But, when one is oblivious to the advantages experienced because of his or her own White privilege, how can one really put oneself in the shoes of the other? A willingness to radically listen, as described by Ken Tobin (2009) to "understand others' texts in terms of their standpoints and axiological commitments" (p. 505) and without judgment, can serve as a beginning step toward the sensitization of the lived reality of the vast amount of pedagogical challenges that are faced by of faculty in higher education because of their race and/ or gender. Unwritten rules must be unveiled, identified, clarified and dealt with in ways that do not harm, but can be addressed straightforwardly - making expectations, practices, beliefs and belief systems openly known. It is when the fear of achievement, the threat of aspiration, the presence of ambition and the drive of a Black male or female faculty member are exposed, when the refusal of being subjugated by those who at the academy's margins is respected, taken seriously and not subject to penalization, and when the perceived threat of these faculty members' demand for dignity and their rights as academic equals to their colleagues are met, it is at this point that possibilities for a true and forward thinking science and science education community can give rise to working and learning environments that benefit the local, national and global outlook of science in the future.

\section{Toward progressive thinking and practices}

Nelson Mandela has said that no one is born hating another person because of the color of his skin, or his background, or his religion (1994). If we are not born racists or sexists, then it is the culture within which we live that teaches us to be racists and sexists. They are resultant factors of environmental influences and, as such, are products of learning. If racism and sexism are learned, then they are educational issues, and if they affect education, then they are matters for educators to confront. The pedagogical challenges presented by racism and sexism start in the working environment of educational departments and continue in the contents and activities programmed and presented to students. Discovering the unwritten rules that affect the dignity and equality of people is in order. Becoming aware that we are all the same and we are all different is essential to drive changes in our immediate environment and expand their effects through the transfer of learning. It is through these efforts that we will contribute to the elimination of sexism and racism from our educational spaces and also from all contexts of coexistence. We need to strengthen our resolve to continue to work more honestly, tactfully and swiftly to address the contentious nature of race and gender. And, in so doing, we model and help others to become more progressive in their thinking as we move consciously away from racist and sexist practices that are grounded in cowardice and fear, toward a more just, confident and strong reality.

\section{References}

Alsubaie, M. A. (2015). Hidden curriculum as one of current issue of curriculum. Journal of Education and Practice, 6(33), 125-128.

Arendt, H. (2004). Eichmann en Jerusalén [Eichmann in Jerusalem]. Barcelona: DeBolsillo.

Arnáiz Sánchez, P., \& Escarbajal Frutos, A. (2012). Reflections about culture, identity and racism from a pedagogical glance. Teoría de la educación, 24(2), 83-106.

Bagnall, R. G. (1999). Discovering radical contingency: Building a postmodern agenda in adult education. New York: Peter Lang Publishing Inc. Barnes, K. J., \& Smith, G. E. (2013). Beyond the textbook: An approach to facilitating student understanding of organizational culture in organizations. Organization Management Journal, 10(1), 45-65. https

://doi.org/10.1080/15416 518.2013.78140 0.

Berger, P. L., Luckmann, T., \& Zifonun, D. (1991). The social construction of reality. London: Penguin 
Books.

BETNetworks. "Michael Eric Dyson shares why Black people can't be racist." Online video clip. YouTube. YouTube, 04 Oct. 2012. Web.6 Jan. 2019.

Braga, M., Paccagnella, M., \& Pellizzari, M. (2014). Evaluating students' evaluations of professors. Economics of Education Review, 41, 71-88. https ://doi.org/10.1016/j.econe durev .2014.04.002.

Capper, C. A. (2015). The 20th-year anniversary of critical race theory in education: Implications for leading to eliminate racism. Educational Administration Quarterly, 51(5), 791-833. https ://doi.org/10.1177/0013161X15 607616.

CDC, Center for Disease Control and Prevention. (2015). U.S. public health service syphilis study at Tuskegee. Retrieved from https ://www.cdc.gov/tuske gee/timel ine.htm. Accessed Jan 2019.

Christian, M. (2017). Race and social identity in the Obama age: A view from behind the Veil. In P. ReidMerrit (Ed.), Race in America: How a pseudoscientific concept shaped human interaction (pp. 125-142). Santa Barbara: Praeger.

Cooper Owens, D. (2017). Medical bondage: Race, gender, and the origins of American gynecology. Athens: University of Georgia Press.

Crenshaw, K. (1989). Demarginalizing the intersection of race and sex: A black feminist critique of antidiscrimination doctrine, feminist theory and antiracist politics University of Chicago Legal Forum, special issue: Feminism in the Law: Theory, Practice and Criticism (pp. 139-168). University of Chicago Law School.

Croom, N. N. (2017). Promotion beyond tenure: Unpacking racism and sexism in the experiences of black women professors. The Review of Higher Education, 40(4), 557-583. https ://doi.org/10.1353/ rhe.2017.0022.

Curry, C. (2013, October 14). Biology-online fires editor who call scientist 'Urban Whore'. Retrieved from https ://abcne ws.go.com/US/biolo gy-onlin e-fires -edito r-calle d-scien tist-urban -whore /story?id=20564 772. Accessed Jan 2019.

Decker, E. N., \& Odom, R. Y. (2018). Publish or Perish: Librarians collaborating to support junior faculty to publish within the academic environment. In Management association, information resources, teacher training and professional development: Concepts, methodologies, tools, and applications (pp. 193-211). Pennsylvania: IGI Global. https ://doi.org/10.4018/978-1-5225-5631-2.ch009 .

Dixson, A. D., \& Rousseau Anderson, C. (2018). Where are we? Critical race theory in education 20 years later. Peabody Journal of Education, 93(1), 121-131. https ://doi.org/10.1080/0161956X.2017.1403194.

Dreher, J. (2003). The symbol and the theory of the life-world: The trascendences of the life-world and their overcoming by sings ad symbols. Dordrecht: Kluwer Academic Publishers.

Ellis, R., \& Hogard, E. (Eds.). (2018). Handbook of quality assurance for university teaching. London: Routledge.

Freire, P. (1972). Pedagogy of the oppressed. Harmondsworth: Penguin.

Godfrey, E. B., \& Wolf, S. (2016). Developing critical consciousness or justifying the system? A qualitative analysis of attributions for poverty and wealth among low-income racial/ethnic minority and immigrant women. Cultural Diversity and Ethnic Minority Psychology, 22(1), 93. https ://doi.org/10.1037/cdp00 00048 .

Goncalo, J. A., Katz, H., \& Ellis, L. M. (2018). Piece Together: How Social Norms Support the Process of Team Creativity. In P. B. Paulus \& B. A. Nijstad (Eds.), The oxford handbook of group creativity. Oxford: Oxford University Press.

Gould, S. J. (1981). The mismeasure of man. New York: Norton.

Grioux, H. A. (2017). The public in Peril (pp. 61-83). New York: Routledge.

Gulbrium, J. F., \& Holstein, J. A. (Eds.). (2002). Handbook of interview research. Context and method. London: Sage.

Haney Lopez, I. F. (2000). The social construction of race. In Richard Del Gado \& Jean Stefancic (Eds.), Critical race theory: The cutting edge (pp. 163-175). Philadelphia: Temple University Press.

Harris-Perry, M. V. (2011). Sister citizen: Shame, stereotypes, and black women in America. New Haven: 
Yale University Press

Hooks, B. (1981). Ain't I a woman? Black women and feminism. New York: Routledge.

Imrie, B. W., Cox, K., \& Miller, A. (2014). Student assessment in higher education: a handbook for assessing performance. New York: Routledge.

Kincheloe, J. L. (1997). Critical research in science education. In B. J. Fraiser \& K. G. Tobin (Eds.), International handbook of science education (Vol. 2, pp. 1191-1205). Dordrecht: Kluwer Academic.

Kincheloe, J. L. (1999). The struggle to define and reinvent whiteness: A pedagogical analysis. College Literature, 26(3), 162-194.

Kincheloe, J. L. (2008). Critical pedagogy (2nd ed.). New York: Peter Lang.

Kirylo, J. D. (Ed.). (2013). A critical pedagogy of resistance. 34 pedagogues we need to know. Rotterdam: Sense Publishers.

Knobloch-Westerwick, S., Glynn, C. J., \& Huge, M. (2013). The Matilda effect in science communication: an experiment on gender bias in publication quality perceptions and collaboration interest. Science Communication, 35(5), 603-625. https://doi.org/10.1177/10755 47012472684.

Law, T., \& Legewie, J. (2018). Urban data science. In R. A. Scott, M. Buchmann, \& S. Kosslyn (Eds.), Emerging trends in the social and behavioral sciences (pp. 1-12). New York: Wiley.

Lawrence, C. R. (2018). If he hollers let him go: Regulating racist speech on campus. In M. J. Matsuda (Ed.), Words that wound. Critical race theory, assaultive speech, and the first amendment (pp.5388). New York: Routledge.

Leath, S., \& Chavous, T. (2017). "We really protested": The influence of sociopolitical beliefs, political self-efficacy, and campus racial climate on civic engagement among black college students attending predominantly white institutions. The Journal of Negro Education, 86(3), 220-237. https ://doi.org/10.7709/jnegr oeduc ation .86.3.0220.

Lee, D. L. (2013, October 11). Responding to no name life science blog editor who called me out of my name [The Urban Scientist]. Retrieved from https ://blogs .scien tific ameri can.com/urban -scien tist/responding -to-no-name-life-scien ce-blog-edito r-who-calle d-me-out-of-my-name/. Accessed Jan 2019.

Linnemanstons, K. A., \& Jordan, C. M. (2017). Learning through place: Evaluation of a professional development program for understanding the impact of place-based education and teacher continuing education needs. Journal of Sustainability Education, 12,25.

Loughran, J. J. (2002). Effective reflective practice: In search of meaning in learning about teaching. Journal of Teacher Education, 53(1), 33-43. https ://doi.org/10.1177/00224 87102053001004.

Madden, P. E., Wong, C., Vera Cruz, A. C., Olle, C., \& Barnett, M. (2017). Social justice driven STEM learning (STEMJ): A curricular framework for teaching STEM in a social justice driven, urban, college access program. Catalyst: A Social Justice Forum, 7(1), Article 4.

Mandela, N. (1994). The long walk to freedom: The autobiography of Nelson Mandela (p. 622). New York: Little, Brown and Company.

Matusov, E., \& Marjanovic-Shane, A. (2017). Many faces of the concept of culture (and education). Culture and Psychology, 23(3), 309-336. https ://doi.org/10.1177/13540 67X16 655460.

Mazer, J. P. (2018). Teachers, students, and ideological bias in the college classroom. Communication Education, 67(2), 254-258. https ://doi.org/10.1080/03634 523.2018.14287 61.

McCaughey, M., \& Cermele, J. (2017). Changing the hidden curriculum of campus rape prevention and education: Women's self defense as a key protective factor for a public health model of prevention. Trauma, Violence and Abuse, 18(3), 287-302. https ://doi.org/10.1177/15248 38015 611674.

McIntosh, P. (1998). White privilege: Unpacking the invisible knapsack. In M. McGoldrick (Ed.), Revisioning family therapy: Race, culture, and gender in clinical practice (pp. 147-152). New York: Guilford Press.

McKittrick, K. (Ed.). (2015). Sylvia Wynter: On being human as praxis. Durham: Duke University Press. 
McMahon, J. M., \& Kahn, K. B. (2018). When sexism leads to racism: Threat, protecting women, and racial bias. Sex Roles, 78(9-10), 591-605. https ://doi.org/10.1007/s1119 9-017-0828-x.

Mekawi, Y., Bresin, K., \& Hunter, C. D. (2017). Who is more likely to "not see race"? Individual differences in racial colorblindness. Race and Social Problems. https ://doi.org/10.1007/s1255 2017-9211-3.

Mitchell, K. M. W., \& Martin, J. (2018). Gender bias in student evaluations. PS: Political Science and Politics, 51(2), 648-652. https://doi.org/10.1017/s1049 0965180000 1x.

Parsons, E., Bulls, D. L., Freeman, T. B., Butler, M. B., \& Atwater, M. A. (2018). General experiences + race + racism $=$ Work lives of Black faculty in postsecondary science education. Cultural Studies of Science Education, 13(2), 371-394. https://doi.org/10.1007/s1142 2-016-9774-0.

Peters, M. A. (2018). The end of neoliberal globalization and the rise of authoritarian populism. Educational Philosophy and Theory, 50(4), 323-325. https ://doi.org/10.1080/00131 857.2017.13057 20.

Plaut, V. C., Thomas, K. M., Hurd, K., \& Romano, C. A. (2018). Do color blindness and multiculturalism remedy or foster discrimination and racism? Current Directions in Psychological Science, 27(3), 200-206. https ://doi.org/10.1177/09637 21418766068.

Popper, K. (1945). The Open Society and Its Enemies. Volume One: The Spell of Plato. London and New York: Routledge and Kegan Paul Ltd.

Rodgers, C. (2002). Defining reflection: Another look at John Dewey and reflective thinking. Teachers College Record, 104(4), 842-866. https ://doi.org/10.1111/1467-9620.00181 .

Scott, D. (2000). The re-enchantment of humanism: An interview with Silvia Wynter. Small Axe: A Caribbean Journal of Criticism, 4(2), 119-207.

Sewell, W. (1999). The concept(s) of culture. In V. Bennett \& L. Hunt (Eds.), Beyond the cultural turn (pp. 35-61). Berkeley: University of California Press.

Skloot, R. (2013, March 23). The immortal life of Henrietta Lacks, the sequel. The New York Times, p. SR4.

Smith, W. (2018). Hole in the head: A life revealed. Meadville: Christian Faith Publishing Inc.

Stronge, J. H. (2018). Qualities of effective teachers (3rd ed.). Alexandría: ASCD.

Sue, D. W., Capodilupo, C. M., Torino, G. C., Bucceri, J. M., Holder, A. M. B., Nadal, K. L., et al. (2007). Racial microagressions in everyday life: Implications for clinical practice. American Psychologist, 62, 271-286. https ://doi.org/10.1037/0003-066X.62.4.271.

Tobin, K. (2009). Tuning into others' voices: Radical listening, learning from difference, and escaping oppression. Cultural Studies of Science Education, 4(3), 505-511. https ://doi.org/10.1007/s1142009-9218-1.

Uttl, B., White, C. A., \& Gonzalez, D. W. (2017). Meta-analysis of faculty's teaching effectiveness: Student evaluation of teaching ratings and student learning are not related. Studies in Educational Evaluation, 54, 22-42. https ://doi.org/10.1016/j.stued uc.2016.08.007.

Valencia, R. R. (2010). Dismantling contemporary deficit thinking: Educational thought and practice. New York: Routledge.

Virtanen, M., \& Elovainio, M. (2018). Justice at the workplace: A review. Cambridge Quarterly of Healthcare Ethics, 27(2), 306-315. https ://doi.org/10.1017/S0963 180117000639.

Vygotsky, L. (1986). Thought and language. Revised Edition. Cambridge: MIT press

Ward, K. M., \& Zarate, M. E. (2015). The influence of campus racial climate on graduate student attitudes about the benefits of diversity. The Review of Higher Education, 38(4), 589-617. https ://doi.org/10.1353/rhe.2015.0034.

Washington, H. A. (2008). Medical apartheid: The dark history of medical experimentation on black Americans from colonial times to the present. Germany:Anchor Books.

Wright, C., Maylor, U., \& Watson, V. (2018). Black women academics and senior managers resisting gendered racism in British higher education institutions. In O. Perlow, D. Wheeler, S. Bethea, \& B. Scott (Eds.), Black women's liberatory pedagogies. Cham: Palgrave Macmillan.

Wynter, S. (1987). On disenchanting discourse: "Minority" literary criticism and beyond. Cultural 
Critique,7, 207-244. https ://doi.org/10.2307/13541 56.

Zack, N. (2018). Race according to biological science. In N. Zack (Ed.), Philosophy of Race (pp. 47-69).

Cham: Palgrave Macmillan. https ://doi.org/10.1007/978-3-319-78729 -9_3.

Gillian Bayne is an associate professor of Science Education at Lehman College of the CUNY. She also holds an appointment in the Urban Education Department at CUNY's Graduate Center. Dr. Bayne is an enthusiastic naturalist and is equally captivated by the beauty of microscopy. She has over 25 years of science education experience, which has helped to deepen not only her passion for science content, but also has been instrumental in shaping both her established and evolving research efforts. Dr. Bayne's ongoing research interests involve utilizing cogenerative dialogues and coteaching to improve the teaching and learning of science, examining the personal and professional trajectories of underrepresented scientists of color and addressing equity issues that are embedded within STEM. An additional and recent research focus involves helping to strengthen the leadership qualities and experiences of Ethiopian professional women in STEM.

Eduardo Dopico is a doctor in Pedagogy and professor at the University of Oviedo (Asturias-Spain), where he teaches Didactics and Educational Innovation. His lines of research are related to the teaching-learning processes in science education. 